\title{
Anatomy of Left Atrioventricular Valve (Mitral Valve) Leaflets in Adult Indian Cadavers
}

\author{
Anatomía de los Velos Valvulares en la Valva Atrioventricular Izquierda \\ (Válvula Mitral) en Cadáveres Indios Adultos
}

Deopujari, R.*; Sinha, U.* \& Athavale, S. A.**

DEOPUJARI, R.; SINHA, U. \& ATHAVALE, S. A. Anatomy of left atrioventricular valve (mitral valve) leaflets in adult Indian cadavers. Int. J. Morphol., 31(4):1276-1281, 2013.

SUMMARY: The atrioventricular valve is the most commonly repaired valve of the heart. Interventional procedures like annuloplasties, valvotomy/valvuloplasty, repair/replacement of the valve for regurgitation or prolapse are increasing by the day. This necessitates a clear understanding of the mitral valve anatomy. The present study is an attempt to revisit the anatomy of mitral valve. The present study was conducted on 34 adult embalmed heart specimens. Based on the newly defined criteria, observations were made on: 1) Number of commissures and their positions, 2) Number and position of leaflets, 3) Number and position of minor commissures, 4) Annular circumference (AC), 5) Length of annular attachment of each leaflet (LAA), 6) Maximum width of coapted/ folded margin (FM) of the anterior and posterior leaflet, 7) The surface area of each leaflet (SA). The observations were analyzed statistically. The findings of the present study and the subsequent statistical analysis offer a dynamic concept of the anatomy of mitral valve leaflets. It suggests that the valvular anatomy depends upon a complex interplay of various valve components. The extra leaflets tend to occur when annular circumference increases and is not appropriately compensated by various valvular elements. The different methodology adopted in the present study and the interpretations deduced hereupon, shall dispel the existing ambiguities in the description of the leaflets and improve our understanding of the structure and function of the mitral valve complex.

KEY WORDS: Annular circumference; Major commissures; Minor commissures

\section{INTRODUCTION}

The atrioventricular (mitral) complex is composed of several elements namely: annulus, leaflets, tendinous cords and papillary muscles (Sinnatamby, 1999; Fuster et al., 2004; Standring et al., 2005). Most important of these elements are the leaflets. Since the times of Andres Vesalius the mitral valve has been presumed to have two leaflets and hence called bicuspid valve. Subsequent workers have followed this conventional nomenclature of the mitral valve leaflets. However, in recent times, divergent views have been reported regarding the number and morphological description of these leaflets (Anderson \& Kanani, 2007). This has resulted in ambiguity regarding the morphology and nomenclature of leaflets (Standring et al.). This ambiguity is mainly a result of different criteria being used to define the valve morphology. The present study proposes to characterize the leaflet morphology of mitral valve in Indian subjects. Knowledge of the leaflets and their annular attachment is necessary for operative procedures like mitral valve annuloplasties.

\section{MATERIAL AND METHOD}

The present study was conducted on thirty four adult hearts procured from the collection of embalmed cadavers available in the department of Anatomy. Since the heart specimen were already removed from the cadaver before the commencement of the study, the sex could not be ascertained. Hearts with any grossly identifiable anomaly and calcific mitral valves were excluded from the study. Hearts were cleaned and cleared from any clots within the chambers. The left atrium and the left ventricle were opened. Annular attachment of the leaflets was ascertained by palpating the annular ring. The attached margin of the valve leaflets was cut along the annular ring. The papillary muscles were cut at their bases to remove the valve leaflets along with chordae tendinae and papillary muscles.

The annular circumference was measured with the help of a thread and ruler. Other measurements were obtained as follows: 
The atrial side of the leaflets in closed position of the valve was opposed to a transparent glass plate placed horizontally. The annular margin, the free margin of the leaflets and the commissures between the leaflets were marked with a marker pen over the glass plate. These markings were then transferred over a translucent butter paper by keeping the paper over the glass plate. Following observations were recorded from each mitral valve tracing:

1) Number of commissures and their positions: The commissures were defined as major and minor based on following criteria:

- Commissures (com) are any indentation in the free margin of the valve.

- Major commissures-indentation more than $2 / 3$ of maximum width of the larger of the two adjacent leaflets.

- Minor commissures--- indentation between $1 / 3$ to $2 / 3$ of maximum width of the larger of the two adjacent leaflets.

2) The number and position of leaflets was noted. A leaflet was defined as part of valve situated between two major commissures.

3) Number and position of minor commissures in each leaflet was also observed. A scallop was defined as a part of leaflet separated out from the main leaflet by a minor commissure.

\section{4) Annular circumference (AC)}

5) Length of annular attachment of each leaflet (A-LAA for anterior and P-LAA for posterior)

6) Maximum width of coapted/ folded margin (FM) of the anterior and posterior leaflet (A-LFM for anterior and P-LFM for posterior).

7) The surface area of each leaflet (A-SA for anterior and PSA for posterior) was calculated by using a digital planimeter.

8) Posterior composite SA (post composite SA) -sum of PSA and extra leaflet (if present) area.

The observations were analyzed statistically. Different study variables were correlated to find out the relationship between them.

\section{RESULTS}

The long axis of the mitral valve orifice was almost vertical in anatomical position of the heart. In such position the larger (anterior) was positioned to the right side and the smaller (posterior) was positioned to the left side of the orifice respectively. The anterior leaflet was semicircular while the posterior leaflet was crescentic in shape (Fig. 1). In majority of heart specimen two leaflets were observed, separated by two major commissures (Fig. 1). One extra leaflet was observed in five heart specimen (Fig. 2) and two in three heart specimen (Fig. 3). In cases of one extra leaflet, the additional major commissure was positioned in either the upper third (3 hearts) or the lower third (2 hearts) of the annular attachment of the posterior leaflet. In cases of two extra leaflets, the major commissures were positioned in the upper and lower thirds of the posterior leaflet attachment.

Single minor commissure was observed in 9 hearts and 2 in 7 heart specimen. Out of all minor commissures observed, 10 were positioned in upper third, 3 in middle third and 10 in lower third. Thirteen hearts had neither any extra major commissure, nor any minor commissures. The folded margin showed great variability. In 3 heart specimen no evidence of folding of the free margin of leaflets could be observed.

The proportion of length of annular attachment of anterior and posterior leaflet was more than 2:3. The surface area of the anterior leaflet was 1.6 times more than the posterior leaflet (Fig. 4) (Table I). To study the interrelationship of different study variables bivariate correlation analysis was done using statistical software SPSS 20 (Table II).

Following interpretations were deduced after studying the correlation coefficients between different study variables:

AC shows:

i) Positive, statistically highly significant correlation with ALAA and A-SA.

ii) Weak but positive correlation with P-LAA and P-SA.

iii) Strong positive correlation with number of extra leaflets.

A-LAA showed:

i) Strong, statistically significant positive correlation with A-

SA, P-SA and posterior composite SA

ii) Negative correlation with number of extra leaflets.

A-LFM showed highly significant positive correlation with P-LFM.

A-SA showed:

i) Significant positive correlation with P-LAA and P-SA and posterior composite SA.

ii) Moderately strong negative correlation with the number of extra leaflet.

Number of minor commissures showed

i) Positive correlation with P-LAA and P-SA, 


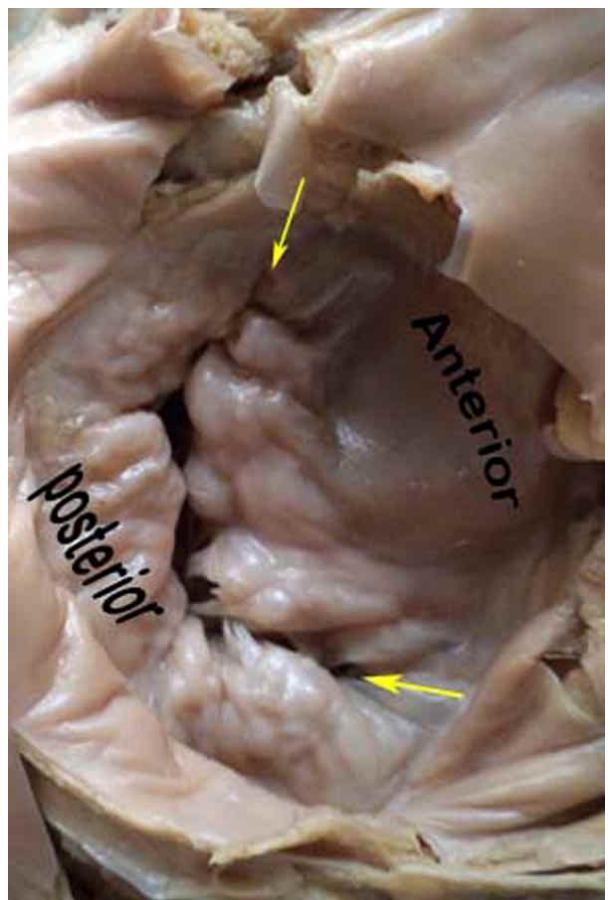

Fig. 1. Showing the mitral valve observed from the atrial side in normal anatomical position of the heart. The major commissures (arrows) separate the two leaflets.

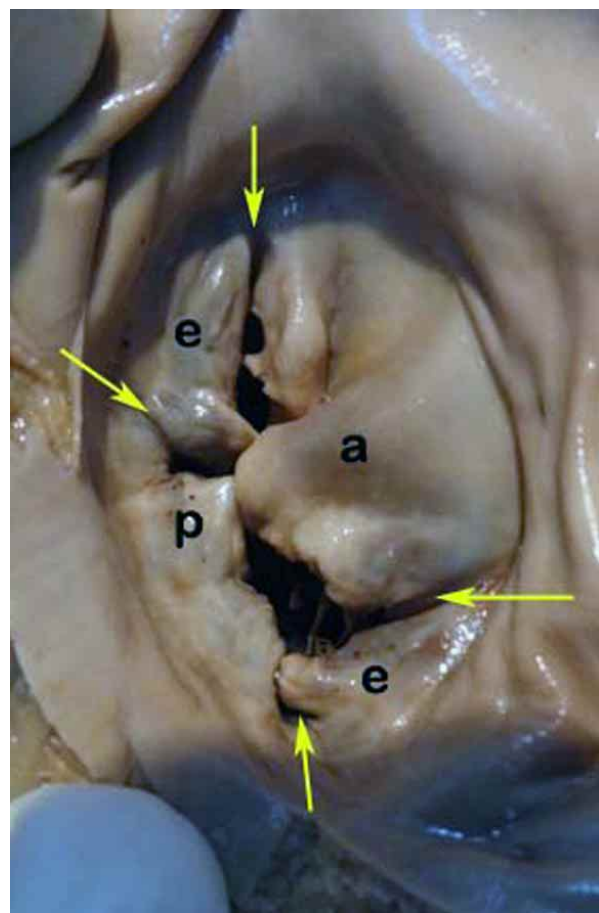

Fig. 3. Showing four major commissures (arrows) and two extra leaflets are seen. a. anterior leaflet, p: posterior leaflet, e: extra leaflet.

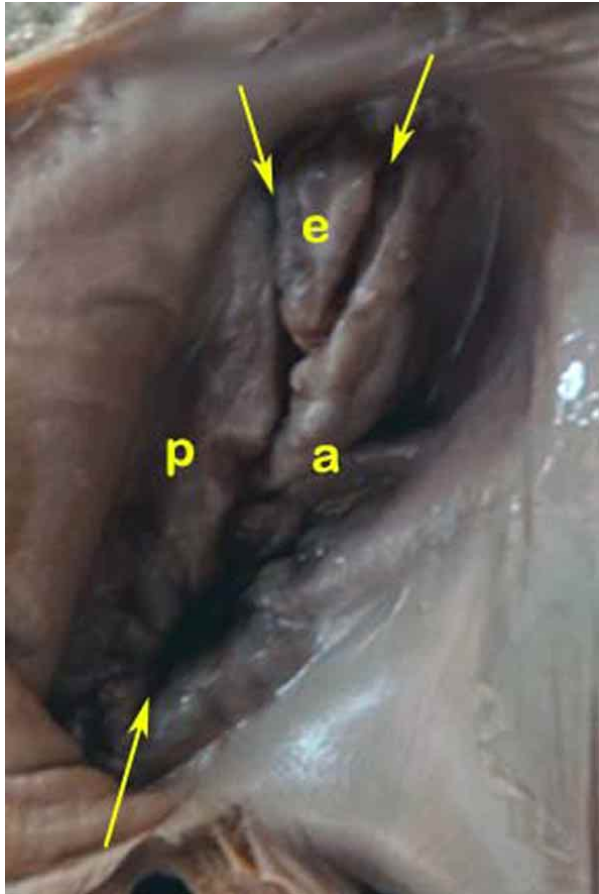

Fig. 2. Showing an extra leaflet, three major commissures (arrows) are seen. a. anterior leaflet, p: posterior leaflet, e: extra leaflet.

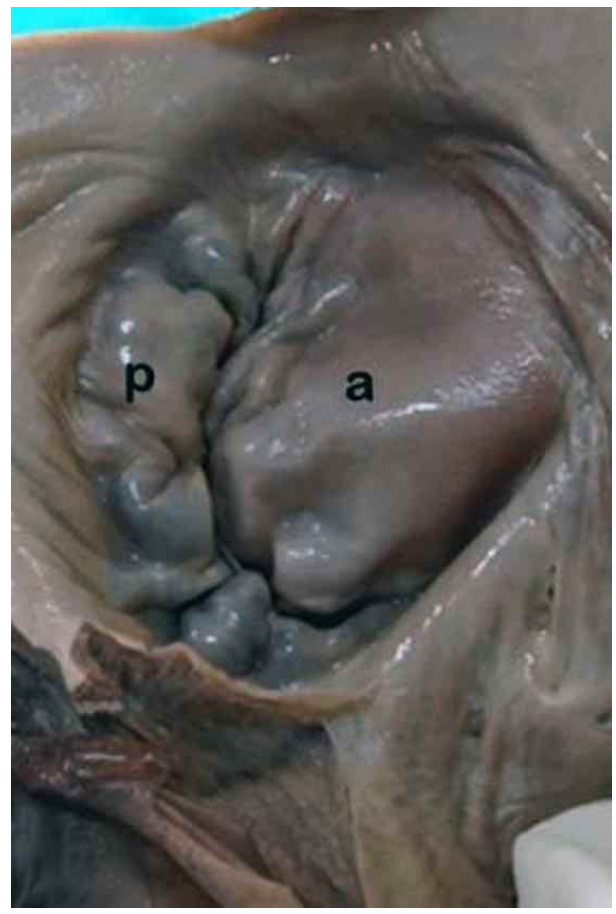

Fig. 4. Showing a large anterior leaflet and a small posterior leaflet. a. anterior leaflet, p: posterior leaflet. ii) Negative correlation with AC, A-LAA, and A-SA and iii) Strong negative correlation with number of extra leaflet.

P-LAA showed highly significant positive correlation with P-SA and post composite $\mathrm{SA}$

Posterior composite SA showed:

i) Positive correlation with AC,

ii) Statistically significant positive with A- LAA, A-SA and P-LAA and P-SA.

iii) Strong positive correlation with extra leaflet area.

Number of extra leaflets showed:

i) Positive correlations with $\mathrm{AC}$ and P-LAA

ii) Negative correlation with A-LAA, A-SA and minor commissures number.

iii) Statistically significant, strong negative correlation with P-SA.

Extra leaflet area showed:

i) Moderate positive correlation with P-LAA, PSA, A-SA

ii) Slight negative correlation with $\mathrm{AC}$ and minor commissures number

P-SA and A-LAA showed moderately strong, negative correlation with major commissures number.

To eliminate the effect of confounding variables, partial correlations were obtained between selected study variables, keeping the confounding variable as control (Table III). 
Table I. Showing descriptive statistics of all study variables.

\begin{tabular}{lcccccc}
\hline & \multirow{2}{*}{ Annular circumference } & \multicolumn{2}{c}{ Anterior leaflet } & \multicolumn{2}{c}{ Posterior leaflet } & Extra leaflet area \\
\cline { 3 - 6 } & & A- LAA & A-SA & P- LAA & P-SA & \\
\hline $\mathrm{n}$ & 34 & 34 & 34 & 34 & 34 & \\
Mean & 8.27 & 3.82 & 3.51 & 5.26 & 2.14 & 0.6000 \\
Std. Deviation & 1.25 & 0.76 & 1.04 & 0.78 & 0.61 & 0.54 \\
Range & 4.70 & 3.70 & 3.84 & 3.30 & 2.73 & 1.00 \\
Minimum & 6.30 & 2.50 & 1.86 & 3.90 & 1.03 & 0.00 \\
Maximum & 11.00 & 6.20 & 5.70 & 7.20 & 3.76 & 1.00 \\
\hline
\end{tabular}

Table II. Shows correlation coefficients of different study variables

\begin{tabular}{|c|c|c|c|c|c|c|c|c|c|c|c|c|}
\hline (2) & 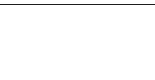 & AC & A- LAA & $\begin{array}{l}\text { A- } \\
\text { LFM }\end{array}$ & A-S A & $\begin{array}{l}\text { Minor } \\
\text { com no. }\end{array}$ & P- LAA & P-LFM & P-SA & $\begin{array}{l}\text { Post. } \\
\text { composite } \\
\text { SA }\end{array}$ & $\begin{array}{l}\text { Extra } \\
\text { leaflet } \\
\text { no. }\end{array}$ & $\begin{array}{l}\text { Extra } \\
\text { leaflet } \\
\text { area }\end{array}$ \\
\hline \multirow[t]{2}{*}{$\overline{\mathrm{AC}}$} & $\begin{array}{l}\text { Pearson } \\
\text { Correlation }\end{array}$ & 1 & $.575(* *)$ & .347 & $.623(* *)$ & -.117 & $.387(*)$ & .273 & .224 & .327 & .501 & -.201 \\
\hline & Sig. (2-tailed) & . & .000 & .056 & .000 & .509 & .024 & .137 & .203 & .059 & .206 & .746 \\
\hline \multirow[t]{2}{*}{ A- LAA } & $\begin{array}{l}\text { Pearson } \\
\text { Correlation }\end{array}$ & $.575(* *)$ & 1 & .027 & $.819(* *)$ & -.078 & .182 & .001 & $.444(* *)$ & $.401(*)$ & -.369 & .193 \\
\hline & Sig. (2-tailed) & .000 & . & .886 & .000 & .663 & .302 & .994 & .009 & .019 & .369 & .756 \\
\hline \multirow[t]{2}{*}{ A-LFM } & $\begin{array}{l}\text { Pearson } \\
\text { Correlation }\end{array}$ & .347 & .027 & 1 & .148 & .181 & -.018 & $.622(* *)$ & .217 & .312 & .539 & .700 \\
\hline & Sig. (2-tailed) & .056 & .886 & . & .427 & .331 & .925 & .000 & .241 & .087 & .168 & .188 \\
\hline \multirow[t]{2}{*}{ A-SA } & $\begin{array}{l}\text { Pearson } \\
\text { Correlation }\end{array}$ & $.623(* *)$ & $.819(* *)$ & .148 & 1 & -.003 & $.341(*)$ & .086 & $.508(* *)$ & $.469(* *)$ & -.419 & .303 \\
\hline & Sig. (2-tailed) & .000 & .000 & .427 & . & .988 & .049 & .647 & .002 & .005 & .301 & .620 \\
\hline \multirow[t]{2}{*}{ Minor com no. } & $\begin{array}{l}\text { Pearson } \\
\text { Correlation }\end{array}$ & -.117 & -.078 & .181 & -.003 & 1 & .109 & .155 & .075 & .032 & -.600 & -.221 \\
\hline & Sig. (2-tailed) & .509 & .663 & .331 & .988 & . & .538 & .404 & .675 & .859 & .116 & .721 \\
\hline \multirow[t]{2}{*}{ P- LAA } & $\begin{array}{l}\text { Pearson } \\
\text { Correlation }\end{array}$ & $.387(*)$ & .182 & -.018 & $.341(*)$ & .109 & 1 & .077 & $.478(* *)$ & $.560(* *)$ & .174 & .476 \\
\hline & Sig. (2-tailed) & .024 & .302 & .925 & .049 & .538 & . & .682 & .004 & .001 & .680 & .418 \\
\hline \multirow[t]{2}{*}{ P-LFM } & $\begin{array}{l}\text { Pearson } \\
\text { Correlation }\end{array}$ & .273 & .001 & $\begin{array}{r}.622( \\
* *)\end{array}$ & .086 & .155 & .077 & 1 & .108 & .156 & .187 & .504 \\
\hline & Sig. (2-tailed) & .137 & .994 & .000 & .647 & .404 & .682 & . & .563 & .403 & .658 & .387 \\
\hline \multirow[t]{2}{*}{ P-SA } & $\begin{array}{l}\text { Pearson } \\
\text { Correlation }\end{array}$ & .224 & $.444(* *)$ & .217 & $.508(* *)$ & .075 & $.478(* *)$ & .108 & 1 & $.840(* *)$ & -.315 & .502 \\
\hline & Sig. (2-tailed) & .203 & .009 & .241 & .002 & .675 & .004 & .563 & . & .000 & .448 & .389 \\
\hline \multirow[t]{2}{*}{ post composite SA } & $\begin{array}{l}\text { Pearson } \\
\text { Correlation }\end{array}$ & .327 & $.401(*)$ & .312 & $.469(* *)$ & .032 & $.560(* *)$ & .156 & $.840(* *)$ & 1 & .106 & .750 \\
\hline & Sig. (2-tailed) & .059 & .019 & .087 & .005 & .859 & .001 & .403 & .000 & . & .803 & .144 \\
\hline \multirow[t]{2}{*}{ Extra leaflet no. } & $\begin{array}{l}\text { Pearson } \\
\text { Correlation }\end{array}$ & .501 & -.369 & .539 & -.419 & -.600 & .174 & .187 & -.315 & .106 & 1 & .(a) \\
\hline & Sig. (2-tailed) & .206 & .369 & .168 & .301 & .116 & .680 & .658 & .448 & .803 & . & . \\
\hline \multirow[t]{2}{*}{ Extra leaflet area } & $\begin{array}{l}\text { Pearson } \\
\text { Correlation }\end{array}$ & -.201 & .193 & .700 & .303 & -.221 & .476 & .504 & .502 & .750 & (a) & 1 \\
\hline & Sig. (2-tailed) & .746 & .756 & .188 & .620 & .721 & .418 & .387 & .389 & .144 & . & . \\
\hline
\end{tabular}

* Correlation is significant at the 0.05 level (2-tailed). ** Correlation is significant at the 0.01 level (2-tailed).

Table III. Partial correlation between i) A-LAA and extra leaflet number, ii) P-SA and extra leaflet number.

\begin{tabular}{lcccc}
\hline S. n & Correlation variables & Correlation & Significance & Control Variables \\
\hline 1 & A- LAA \& Extra leaflet number & -0.429 & 0.016 & Annular circumference \& P- LAA \& MINOR COM NO. \\
2 & P-SA \& Extra leaflet number & -0.490 & 0.004 & A-SA \\
\hline
\end{tabular}




\section{DISCUSSION}

Study of mitral valve leaflets in the present work was conducted in opposed position of the valve as observed from the atrial aspect. Authors believe that this description is more close to the real life visualization of the valve by clinicians. As against the conventional description of the morphology and morphometry of the valve in open position by anatomists the present study clearly delineates the operational area and the folded margin of the valve.

The conventional descriptions of the valve leaflets as anterior and posterior are also misnomers. The leaflets were more aligned towards right and left separated by a near vertical orifice. The anterior leaflet was semicircular while posterior was crescentic.

Quill et al. (2009) also disapproved the use of the terms anterior and posterior leaflets as these were based upon examination of a specimen in the so-called "valentine" position, with the heart oriented such that the interventricular septum is parallel to the long axis of the body, with the apex positioned inferiorly and not in the anatomical position.

Anderson \& Kanani in their critical analysis of mitral valve have discussed the various descriptions about the variability in number of leaflets and conclude that interpretations may vary depending upon criteria used to define them. The criterion used, in the present study, for delineating different leaflets differs from that of previous studies. Previous studies have utilized i) attachment of chordae tendinae arising from apex of papillary muscle (Victor \& Nayak, 1995, Anderson \& Kanani), and ii) type of chordae (Ranganathan et al., 1970). Both these criteria are not dependable due to great variability of papillary muscle (Rusted et al., 1952, as quoted by Ho, 2002) and chordae (Lam et al., 1970; Becker \& de Witt, 1980, as quoted by Anderson \& Kanani).

Lalwani et al. (2010), have described the mitral valve to be like a veil around the mitral orifice whose free margins show indentations, the anterolateral and posterolateral commissures dividing it into anterior and posterior leaflets.

The criterion used in present study was based on indentation of valve leaflets. This criterion was formulated with the contention that deeper indentations increase independence in functionality (movement of leaflets) and hence can be appropriately called extra commissures delineating extra leaflets. Although, descriptions of such deep indentation do exist, especially in clinical literature (Fuster et al.; Anderson \& Kanani) and have also been implicated in causation of mitral valve prolapsed in a recent study (Ring et al., 2013), workers have refrained from describing them as commissures and considering presence of extra leaflet. However Yacoub \& Kumar et al. (as quoted by Anderson \& Kanani) have suggested number of leaflets to be 4 and 6 respectively.

The present investigation suggests a dynamic concept of mitral valve leaflets. It suggests the number of leaflet may vary depending on the annular circumference and the interplay of various components and parameters of different cusps of mitral valve. This interpretation is deduced from statistical analysis of morphometry of valve leaflets as follows. The proportion of lengths of attachment of anterior and posterior leaflet was more than $2: 3$ as against 1:2 described by Ho and Fuster et al. Available literature suggests that surface area of both the leaflets is equal (Fuster et al.). However in opposed position of valve, as observed in present study, the surface area of anterior leaflet was 1.6 times more than the posterior leaflet. The present investigation suggests that extra leaflets tend to occur when annular circumference increases. This increase in annular circumference, if not compensated by proportionate increase of A-LAA and hence A-SA, increases the chances of formation of extra leaflets. Increase in annular circumference may also be compensated by increase in P-LAA and P-SA and formation of minor commissures in posterior leaflet (to compensate for movement compromised by increase P-LAA). If P-LAA and $\mathrm{P}-\mathrm{SA}$ do not increase proportionately and minor commissures do not appear, then there are increased chances of occurrence of extra leaflet. However the strength of correlation of annular circumference is stronger with anterior leaflet (ALAA-.575**, A-SA-.623**) as compared to that of posterior (P-LAA .387*, P-SA-.224). An increase in annular circumference is thus expected to show a proportionate increase in anterior leaflet rather than that of posterior. Our contention that anterior leaflet, in cases of increased annular circumference, is stronger determinant of occurrence of extra leaflet, is well reflected in a stronger negative correlation with number of leaflet.

\section{CONCLUSIONS}

The orifice of the mitral valve is almost vertical in anatomical position and the so called anterior and posterior leaflets are oriented to the right and left of the orifice.

The proportion of length of annular attachment of anterior and posterior leaflet was more than 2:3. In opposed position of valve, the surface area of anterior leaflet was 1.6 times more than the posterior leaflet. 
Around two third heart specimen (21/34) showed presence of an extra major commissure or a minor commissures giving rise to extra leaflets or scallops respectively.

Around 15\% heart specimen showed presence of
Annular circumference emerged as a major determinant of occurrence of extra leaflets. An increase in annular circumference, if not compensated by appropriate increase in anterior leaflet tends to result in formation of an extra leaflet. extra leaflet.

DEOPUJARI, R.; SINHA, U. \& ATHAVALE, S. A. Anatomía de los velos valvulares de la valva atrioventricular izquierda (válvula mitral) en cadáveres indios adultos. Int. J. Morphol., 31(4):1276-1281, 2013.

RESUMEN: La valva atrioventricular es la valva más comúnmente reparada del corazón. Los procedimientos intervencionistas como anuloplastías, valvotomía/valvoplastía, reparación/reemplazo de la valva por la regurgitación o prolapso están aumentando día a día. Para ello, se requiere una clara comprensión de la anatomía de la valva atrioventricular. El presente estudio intenta volver a examinar la anatomía de la valva atrioventricular. Se estudiaron 34 corazones de adultos embalsamados. Sobre la base de los criterios definidos, se realizaron las siguientes observaciones: 1) número de comisuras y sus posiciones, 2) número y localización de los velos, 3) número y localización de las comisuras menores, 4) circunferencia anular (AC), 5) longitud de la unión anular de cada valva (LAA), 6) ancho máximo del margen de coaptación/margen velar (FM) de los velos anterior y posterior y 7) área de superficie de cada valva (SA). Las observaciones fueron analizadas estadísticamente. Los resultados del presente estudio y el análisis estadístico ofrecen un concepto dinámico de la anatomía de la valva atrioventricular. Se sugiere que la anatomía de las valvas depende de una interacción compleja de varios de sus componentes. Los velos adicionales tienden a aparecer cuando aumenta la circunferencia anulares y no se compensa adecuadamente por diversos elementos valvares. La diferente metodología adoptada en el presente estudio sus interpretaciones, podrían disipar ambigüedades existentes en la descripción de las valvas y mejorar nuestra comprensión de la estructura y función del complejo de la valva atrioventricular.

PALABRAS CLAVE: Circunferencia anular; Comisuras principales; Comisuras menores.

\section{REFERENCES}

Anderson, R. H. \& Kanani, M. Mitral valve repair: Critical analysis of the anatomy discussed. MMCTS, 0219:doi 10.1510/ mmcts.2006.002147, 2007.

Fuster, V.; Alexander, R. W.; O’Rourke, R. A. Hurst's RA The heart. $11^{\text {th }}$ ed. New York, McGraw-Hill, 2004.

Ho, S. Y. Anatomy of the mitral valve. Heart, 88(Suppl. 4):5-10, 2002.

Lam, J. H.; Ranganathan, N.; Wigle, E. D. \& Silver, M. D. Morphology of the human mitral valve. I. Chordae tendinae: a new classification. Circulation, 41(3):449-58, 1970.

Lalwani, R.; Kumar, P.; Aneja, G. K. \& Ramesh Babu, C. S. An echocardiographic study of mitral valve leaflets in western U.P. population. J. Anat. Sci., 18(2):1-5, 2010.

Quill, J. L.; Hill, A. J.; Laske, T. G.; Alfieri, O. \& Laizzo, P. A. Mitral leaflet anatomy revisited. J. Thorac. Cardiovasc. Surg., 137(5):1077-81, 2009.

Ranganathan, N.; Lam, J. H. C.; Wigle, E. D. \& Silver, M. D. Morphology of the Human Mitral Valve: II. The Valve Leaflet. Circulation, 41:459-67, 1970

Ring, L.; Rana, B. S.; Ho, S. Y. \& Wells, F. S. The prevalence and impact of deep clefts in the mitral leaflets in mitral valve prolapsed. Eur. Heart J. Cardiovasc. Imaging, 14(6):595-602, 2013.

Sinnatamby, C. S. Last's Anatomy. $10^{\text {th }}$ ed. London, Churchill Livingstone, 1999.

Standring, S.; Ellis, H.; Healy, J. C.; Johnson, D. \& Williams, A. Gray's Anatomy. 39 $9^{\text {th }}$ ed. New York, Churchill Livingstone, 2005.

Victor, S. \& Nayak, V. M. Variations in the papillary-muscles of the normal mitral valve and their surgical relevance. J. Card. Surg., 10(5):597-607, 1995.

\section{Correspondence to: Dr. Sunita Athavale Associate Professor, Department of Anatomy All India Institute of Medical Sciences, Bhopal, 462024 INDIA}

Email: sunita.anatomy@aiimsbhopal.edu.in

Received: 02-02-2013

Accepted: 08-09-2013 